\title{
Kecemasan Geometri Siswa dalam Menyelesaikan Masalah Bangun Ruang Sisi Datar Ditinjau dari Teori Van Hiele
}

\author{
Erfan Yudianto ${ }^{1}$, Yufrida Septi Nindya ${ }^{2}$, Toto' Bara Setiawan ${ }^{3}$ \\ 1, 2, 3 Program Studi Pendidikan Matematika, Fakultas Keguruan dan Ilmu Pendidikan, Universitas Jember, \\ Jl. Kalimantan No 37, Jember, Indonesia \\ Email penulis pertama: erfanyudi@unej.ac.id
}

\begin{abstract}
Geometry anxiety is anxiety that arises when dealing with things related to geometry. Geometry anxiety levels start at low, medium, high, and panic. The purpose of this research was to describe student's geometric anxiety in solving the problem of flat-sided shapes in terms of van Hiele's theory. This type of research is a qualitative descriptive study. The subjects of this research were two students each at the level of visualization, analysis, and informal deduction. The data collection technique is done through a combination (triangulation). The results of this study indicate that students of each level have different geometric anxiety. Visualization students have medium and high anxiety in defining and identifying the properties and elements of flat-sided shapes. Analysis students have medium anxiety in solving geometry problems related to the calculation of diagonals, volume, and surface area. Informal deduction students have high anxiety in solving problems related to the definition and elements of building space and problems in the form of stories.
\end{abstract}

Keywords: Anxiety; Geometry; van Hiele

\begin{abstract}
Abstrak
Kecemasan geometri adalah kecemasan yang muncul ketika menghadapi hal - hal yang berhubungan dengan geometri. Tingkatan kecemasan geometri dimulai dari rendah, sedang, tinggi, dan panik. Tujuan dari penelitian ini adalah untuk mendeskripsikan kecemasan geometri siswa dalam menyelesaikan masalah bangun ruang sisi datar ditinjau dari teori van Hiele. Jenis penelitian ini yaitu penelitian deskriptif kualitatif. Subjek penelitian ini masing - masing dua siswa pada level visualisasi, analisis, dan deduksi informal. Teknik pengumpulan data dilakukan melalui kombinasi (triangulasi). Hasil penelitian ini menunjukkan bahwa siswa dari tiap level memiliki kecemasan geometri yang berbeda. Siswa visualisasi mengalami kecemasan sedang dan tinggi dalam mendefinisikan dan mengidentifikasi sifat serta unsur bangun ruang sisi datar. Siswa analisis mengalami kecemasan sedang dalam menyelesaikan masalah geometri yang berkaitan dengan perhitungan diagonal, volume, dan luas permukaan. Siswa deduksi informal mengalami kecemasan tinggi dalam menyelesaikan masalah berkaitan dengan definisi dan unsur bangun ruang serta permasalahan dalam bentuk cerita.
\end{abstract}

Kata kunci: Kecemasan, Geometri, van Hiele

Copyright (c) 2021 Erfan Yudianto, Yufrida Septi Nindya, Toto’ Bara Setiawan

$\triangle$ Corresponding author: erfanyudi@unej.ac.id

Email Address: erfanyudi@unej.ac.id (Jl. Kalimantan No 37, Jember)

Received 07 Februari 2021, Accepted 23 April 2021, Published 23 April 2021

\section{PENDAHULUAN}

Pendidikan sangat berperan penting bagi manusia untuk memberikan pengetahuan, wawasan, dan keterampilan tertentu kepada individu guna mengembangkan potensi ilmu pengetahuan dan teknologi seperti saat ini. Pendidikan dikatakan berhasil apabila tujuan dari pendidikan dapat tercapai, keberhasilan pendidikan sangat bergantung pada proses belajar dan pembelajaran. Belajar dan pembelajaran merupakan suatu bentuk edukasi yang menciptakan interaksi antara guru dan siswa. Tujuan pembelajaran matematika di sekolah salah satunya yakni pemahaman terhadap konsep matematis. 
Kecemasan Geometri Siswa dalam Menyelesaikan Masalah Bangun Ruang Sisi Datar Ditinjau dari Teori Van Hiele, Erfan Yudianto, Yufrida Septi Nindya, Toto' Bara Setiawan

Geometri merupakan salah satu bagian dari materi matematika yang memiliki hubungan erat dengan bagian-bagian lain dalam matematika. Di lapangan ditemukan bahwa hasil belajar geometri masih rendah, hal ini merupakan salah satu tanda bahwa siswa mengalami permasalahan dalam mempelajari matematika terutama yang berkaitan dengan geometri. Geometri yang dianggap momok bagi siswa dapat menumbuhkan kecemasan saat siswa berhadapan dengannya (Anita, 2014). Menurut penelitian Annisa \& Ifdil (2016), kecemasan adalah keadaan emosi negatif yang ditandai dengan adanya firasat dan ketegangan fisik, seperti detak jantung, berkeringat, kesulitan bernapas. Stuart (2006) mengungkapkan kecemasan dapat ditunjukkan oleh indikator-indikator yang ada dalam gejala fisiologis dan gejala perilaku seseorang. Sedangkan kecemasan geometri adalah kecemasan yang muncul ketika menghadapi hal-hal yang berhubungan dengan geometri. Kecemasan dalam belajar geometri akan membuat sulit berpikir dan berkonsentrasi akibatnya berpengaruh pada prestasi belajar, selain itu kecemasan juga mempengaruhi siswa dalam menyelesaikan masalah Auliya (2016). Menurut teori van Hiele, seseorang akan melalui lima level hierarkis pemahaman dalam belajar geometri (Fuys, Geddes, \& Tischler, 1998). Kelima level tersebut ialah visualisasi, analisis, deduksi informal, deduksi, dan rigor. Tujuan penelitian ini adalah mendeskripsikan kecemasan geometri siswa dalam menyelesaikan masalah bangun ruang sisi datar ditinjau dari teori van Hiele.

\section{METODE}

Jenis penelitian ini adalah jenis penelitian deskriptif dengan menggunakan pendekatan kualitatif. Penelitian kualiatatif adalah penelitian yang dilakukan dengan tujuan untuk memahami fenomena tentang apa yang dialami oleh subjek penelitian Moleong (2010). Fokus pada penelitian ini adalah kecemasan yang terjadi pada siswa dalam menyelesaikan masalah bangun ruang sisi datar. Subjek penelitian adalah siswa kelas XI IPS 1 dan XI IPS 2 SMA Negeri 2 Jember. Pengambilan subjek penelitian dilakukan dengan metode purposive sampling. Pengambilan subjek secara sengaja sesuai dengan persyaratan yang diperlukan yakni siswa terlebih dahulu diberikan tes pelevelan van Hiele pada tanggal 20 November 2020 yang dikenal dengan istilah van Hiele Geometry Test (VHGT). Calon subjek diberikan tes VHGT yang terdiri dari 25 soal dan setiap 5 soal merupakan soal pada level van Hiele. Jumlah siswa yang mengikuti tes sebanyak 63 siswa yang kemudian dipilih 2 siswa sebagai subjek dari masing-masing level yang tersedia. Hal ini mempertimbangkan tiga hal yaitu (1) skor VHGT yang diperoleh siswa, (2) komunikasi siswa yang baik, dan (3) kesediaan siswa untuk dijadikan subjek penelitian. Jumlah subjek terpilih sebanyak 6 siswa dari masing-masing level visualisasi, analisis, dan deduksi informal, sedangkan untuk level deduksi dan rigor tidak diperoleh pada penelitian ini.

Prosedur penelitian dilakukan dengan 7 langkah yaitu (1) kegiatan pendahuluan seperti melakukan studi kepustakaan, menentukan judul penelitian, serta menentukan rumusan masalah dalam penelitian; (2) menyiapkan instrumen penelitian yaitu VHGT (tes 1), tes bangun ruang sisi datar (tes 2), angket kecemasan geometri, pedoman wawancara, serta lembar validasi; (3) validasi instrumen penelitian yang divalidasi oleh dua dosen pendidikan matematika. Kegiatan validasi tes bangun ruang 
sisi datar memperoleh skor akhir 8,875 (skala 10), validasi angket kecemasan geometri 9,43 (skala 10), dan validasi pedoman wawancara memperoleh skor akhir 9 (skala 10). Skor akhir tersebut menunjukan bahwa ketiga instrumen memenuhi kategori valid dan dapat digunakan untuk pengumpulan data; (4) penentuan subjek penelitian yaitu siswa yang telah melakukan tes geometri van Hiele. Setelah mendapatkan subjek, maka dilakukan pengkodean yaitu subjek 1 (S1) dengan DPP dan subjek 2 (S2) dengan JS adalah subjek terpilih dengan level visualisasi, subjek 3 (S3) dengan FRM dan subjek 4 (S4) dengan TRPJ adalah subjek terpilih dengan level analisis, serta subjek 5 (S5) dengan EDP dan subjek 6 (S6) dengan EZP adalah subjek dengan level deduksi informal. Sebagai informasi tambahan bahwa kode-kode tersebut adalah insial nama semua subjek terpilih; (5) pengumpulan data melalui tes, angket dan wawancara. Tes dilakukan untuk mengetahui level berfikir geometri siswa yang kemudian dipilih menjadi subjek penelitian. Angket yang digunakan yaitu angket kecemasan geometri untuk mengetahui gejala kecemasan apa yang dirasakan oleh subjek pada saat menghadapi masalah geometri. Wawancara dilakukan untuk memperoleh penjelasan dari siswa untuk memperkuat data yang lainnya. Pada kegiatan wawancara peneliti memberikan pertanyaan secara individu kepada S1 sampai dengan S6; (6) analisis data, langkah ini dilakukan dengan menyusun data sesuai dengan fokus kajian masalah dan tujuan penelitian; dan (7) kesimpulan, peneliti melakukan penarikan kesimpulan dari hasil analisis data yang diperoleh pada saat melakukan penelitian.

\section{HASIL DAN DISKUSI}

\section{Hasil}

Van Hiele menjelaskan bahwa berdasarkan pengalaman belajar geometri, siswa dapat dibagi menjadi 5 level antara lain level visual, level analisis, level deduksi informal, level deduksi dan level rigor. Dalam perjalanan teori van Hiele ini, Sunardi (2001) melaporkan temuan yang menghasilkan level tambahan sebelum level visual yaitu pre-visual, sehingga pada penelitian ini ditambahkan 1 level lagi yaitu level pre-visual (pre-0). Hasil tes VHGT terhadap 63 siswa calon subjek disajikan pada tabel berikut.

Tabel 1. Persentase Hasil Tes van Hiele

\begin{tabular}{|c|l|c|c|}
\hline No & \multicolumn{1}{|c|}{ Level van hiele } & Banyak Siswa & Persentase (\%) \\
\hline 1 & Pre 0 (Pre visualsasi) & 26 & 41 \\
\hline 2 & 0 (Visualisasasi) & 26 & 41 \\
\hline 3 & 1 (Analisis) & 6 & 9,5 \\
\hline 4 & 2 (Deduksi Informal) & 5 & 8,5 \\
\hline 5 & 3 (Deduksi) & 0 & 0 \\
\hline 6 & 4 (Rigor) & 0 & 0 \\
\hline & TOTAL & 63 & 100 \\
\hline
\end{tabular}

Subjek terpilih kemudian diberikan tes geometri bangun ruang sisi datar dan masing-masing subjek setelah mengerjakan tes 2 kemudian diberi angket kecemasan geometri. Pengisian angket 
Kecemasan Geometri Siswa dalam Menyelesaikan Masalah Bangun Ruang Sisi Datar Ditinjau dari Teori Van Hiele, Erfan Yudianto, Yufrida Septi Nindya, Toto' Bara Setiawan

dilakukan sesuai dengan keadaan/kondisi yang dialami subjek pada saat mengerjakan tes bangun ruang sisi datar, tetapi wawancara dilaksanakan setelah subjek mengerjakan tes 2. Analisis angket kecemasan geometri didasarkan pada indikator kecemasan menurut Stuart. Stuart (2006) menjabarkan angket yang berisikan 25 pernyataan yang harus dijawab oleh subjek. Pilihan yang disediakan berupa penilaian sangat sesuai, sesuai, ragu-ragu, tidak sesuai, dan sangat tidak sesuai. Masing-masing pilihan secara runtut memiliki skor 5,4,3,2, dan 1, sehingga dalam analisis diperoleh semakin besar total nilai angket maka tingkat kecemasan akan semakin tinggi, dengan pengkategorian kecemasan rendah jika total nilai angket $25 \leq x<50$, kecemasan sedang dengan rentang $50 \leq x<75$, kecemasan tinggi $75 \leq x<100$, dan panik saat rentang nilai $100 \leq x \leq 125$. Hasil angket kecemasan geometri siswa dapat dilihat pada tabel berikut.

Tabel 2. Tingkat Kecemasan Geometri Subjek

\begin{tabular}{|c|c|c|c|c|}
\hline No & Nama Subjek & Level van Hiele & Total Nilai Angket & Tingkat Kecemasan \\
\hline 1 & DPP & Visualisasi & 62 & Sedang \\
\hline 2 & JS & Visualisasi & 89 & Tinggi \\
\hline 3 & FRM & Analisis & 52 & Sedang \\
\hline 4 & TRPJ & Analisis & 56 & Sedang \\
\hline 5 & EDP & Deduksi Informal & 82 & Tinggi \\
\hline 6 & EZP & Deduksi Informal & 81 & Tinggi \\
\hline
\end{tabular}

Berdasarkan hasil penelitian yang ternyata subjek cenderung mengalami kecemasan sedang dan tinggi hal ini berbeda dengan hasil yang dilakukan oleh Sunardi et al., (2019) yaitu sebanyak 3 siswa memiliki kecemasan rendah, 42 siswa memiliki tingkat kecemasan sedang, dan 9 siswa dengan kecemasan tinggi, sehingga pada diperoleh rata-rata kecemasan siswa berada pada tingkat kecemasan sedang.

Subjek S1 tidak mengalami kecemasan dengan gejala fisiologis jika dilihat dari hasil angket. Namun S1 mengalami kecemasan pada gejala perilaku seperti mendadak lupa materi, khawatir dan mengalami kebingungan. Subjek S1 mengalami kecemasan dalam mengidentifikasi serta mendefinisikan bangun ruang sisi datar seperti soal pada nomor 1 dan 2. Berikut hasil jawaban S1 dengan tingkat kecemasan sedang.

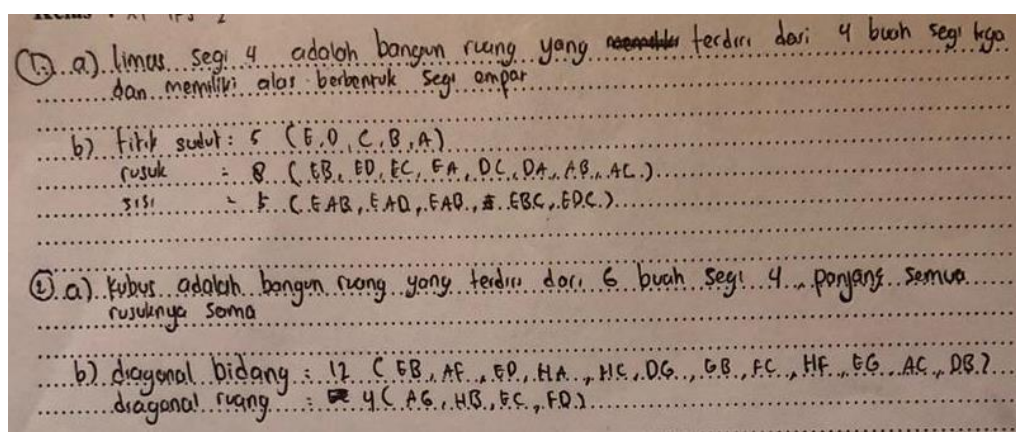

Gambar 1. Jawaban S1 Soal Nomor 1 dan 2 
Selanjutnya untuk menelusuri lebih dalam mengenai kecemasan geometri S1 dilakukan kegiatan wawancara terkait angket dan jawaban subjek, berikut kutipan wawancara dengan Subjek S1.

P101 : apa kamu menjadi lupa materi saat mengerjakan tes geometri tadi? Kamu emang tipe pelupa apa karena cemas sewaktu ngerjakan?

S101 : ya, saya emang kadang lupa materi kalo sudah terdesak gitu ya bisa dibilang cemas sih. Kayak bingung mau jawab apa padahal sebenernya ya sudah tau materinya gitu

P102 : berarti sempat bingung juga ya, terus kamu emang ngerasa takut misal gak bisa jawab?

S102 : iya ... saya takut, misal kayak soal nomer 4 tadi itu. Saya kan sudah berusaha tapi belum bisa juga, terus yang lain udah selesai makin panik saya

P103 : berarti kamu ingin cepat nyelesaiin soal tadi ya? Gara-gara temennya udah pada selesai apa emang udah pasrah aja gitu?

S103 : sebenernya gara-gara temen sudah banyak yang selesai seh, jadi saya gupuh ngerjakannya

P104 : kamu ngerasa terganggu sewaktu temenmu selesai ngerjakan terus gaduh gitu?

S104 : banget, saya emang gak bisa mikir kalo suasananya gak tenang gitu

P105 : dari tes geometri tadi, kamu ngerasa mengalami kecemasan berarti? kesulitanmu di nomor berapa yang sampai akhirnya bikin kamu cemas?

S105 : dari nomor 1 sudah bingung, bukan bingung sih tapi gimana ya. Saya tau itu bangun apa tapi sewaktu menuliskan definisi bangun itu bingung kata-katanya, jadi saya ya jawab kayak apa gambarnya aja hehe

Subjek S1 mendefinisikan limas segiempat dengan menyebutkan bagian-bagian pada gambar, seperti 4 buah segitiga dan alas berbentuk segiempat. Namun, jawaban S1 masih belum tepat dalam menyebutkan sisi limas. S1 mendefinisikan kubus sebagai bangun ruang dengan 6 buah segiempat dan panjang semua rusuknya sama, dan ternyata subjek S1 tidak menjawab soal tentang bidang diagonal. Jawaban subjek S1 pada soal nomor 1 dan 2 tidak menyebutkan sifat-sifat dari bangun ruang dan hanya mendefinisikan berdasarkan karakteristik visual atau penampakan keseluruhan saja. Saat kegiatan wawancara S1 menegaskan kembali bahwa dirinya mengalami beberapa gejala kecemasan perilaku kognitif dan afektif. Berdasarkan penelitian yang dilakukan subjek S1 mengalami kecemasan kategori sedang.

Subjek S2 mengalami kecemasan ditinjau dari gejala fisiologis, seperti pada jantung berdebar, dada terasa seperti ada tekanan, berkeringat dan ingin buang air kecil. Subjek S2 juga mengalami gejala perilaku seperti sulit berkonsentrasi, lupa materi, gelisah, khawatir, takut gagal dan bingung. Subjek S2 cemas dalam mengidentifikasi sifat dan unsur bangun ruang sisi datar. Berikut hasil jawaban S2 dengan tingkat kecemasan tinggi.

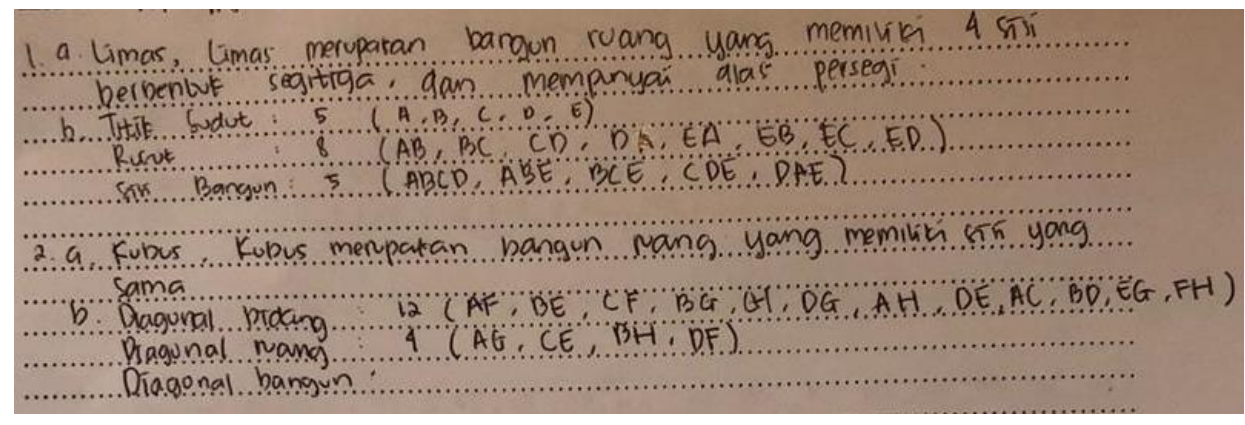


Kecemasan Geometri Siswa dalam Menyelesaikan Masalah Bangun Ruang Sisi Datar Ditinjau dari Teori Van Hiele, Erfan Yudianto, Yufrida Septi Nindya, Toto' Bara Setiawan

Gambar 2. Jawaban S2 Soal Nomor 1 dan 2

Selanjutnya untuk menelusuri lebih dalam mengenai kecemasan geometri S2 dilakukan kegiatan wawancara terkait angket dan jawaban subjek, berikut kutipan wawancara dengan Subjek S2.

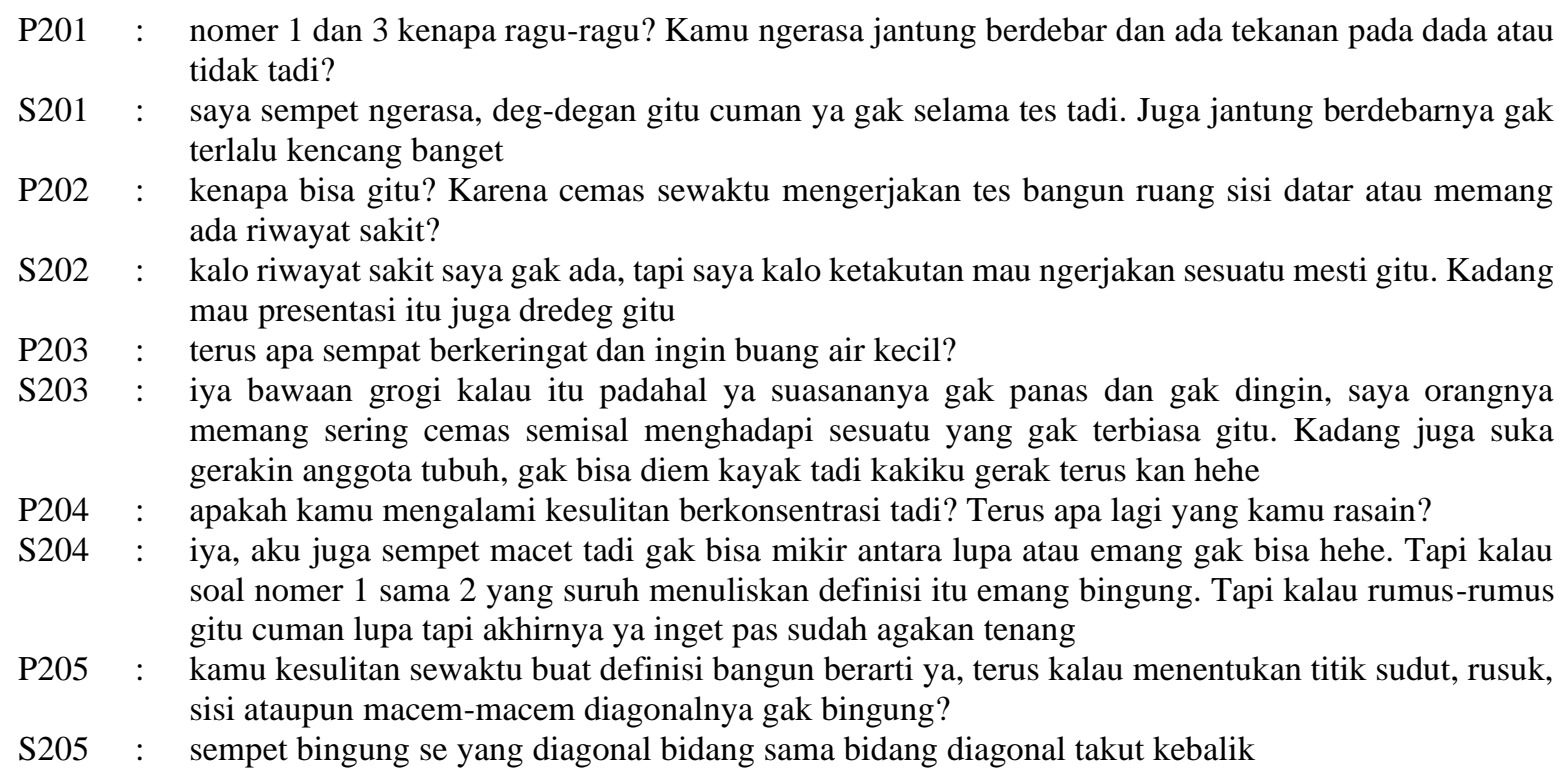

Subjek S2 mendefinisikan limas sebagai bangun ruang yang memiliki 4 sisi berbentuk segitiga dan alas persegi. S2 mendefinisikan kubus sebagai bangun ruang yang memiliki sisi yang sama, dan ternyata subjek S2 tidak menjawab soal tentang bidang diagonal. Jawaban subjek S2 pada soal nomor 1 dan 2 sudah mampu menyebutkan unsur bangun ruang yakni sisi dan mendefinisikan bangun berdasarkan penampakan keseluruhan. Saat kegiatan wawancara S2 menegaskan kembali bahwa dirinya mengalami beberapa gejala kecemasan baik itu fisiologis ataupun perilaku kognitif dan afektif. Berdasarkan penelitian yang dilakukan subjek S2 mengalami kecemasan kategori tinggi.

Subjek S3 mengalami sedikit kecemasan jika dilihat dari gejala fisiologis seperti jantung berdebar dan berkeringat. S3 mengalami gejala perilaku dalam kecemasan seperti bingung, takut, dan kesulitan berkonsentrasi. Subjek S3 mengalami kecemasan dalam menyelesaikan permasalahan geometri yang berhubungan dengan menghitung diagonal, volume, dan luas permukaan. Berikut hasil jawaban S3 dengan tingkat kecemasan sedang.

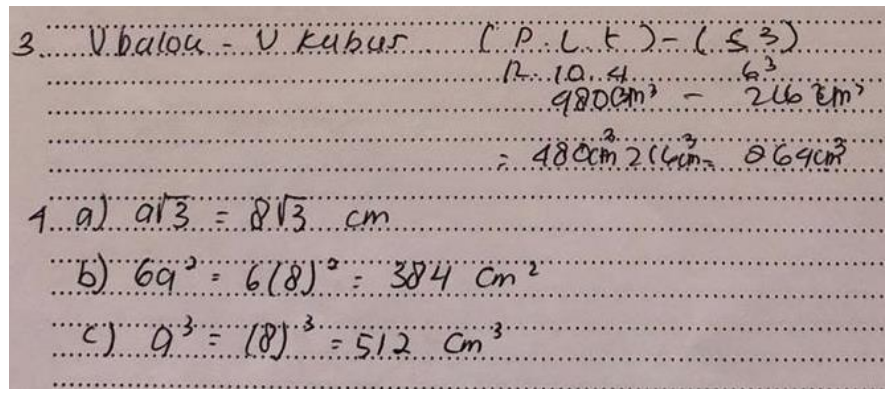

Gambar 3. Jawaban S3 Soal Nomor 3 dan 4 
Selanjutnya untuk menelusuri lebih dalam mengenai kecemasan geometri S3 dilakukan kegiatan wawancara terkait angket dan jawaban subjek, berikut kutipan wawancara dengan Subjek S3.

P301 : tadi sewaktu mengerjakan apa merasa jantung berdebar?

S301 : iya, saya mengalami jantung berdebar

P302 : apa memang ada riwayat sakit atau karena cemas karena mengerjakan tes? Sempat berkeringat juga ya?

S302 : sedikit cemas sih, iya saya berkeringat. Jadi saya awal dapet soal itu bu ngerasa cemas Karena kan gak tau soal tesnya kayak gimana

P303 : kamu sering ngerasa jantung berdebar gini gak?

S303 : jarang, cuman di situasi tertentu aja

P304 : pernyataan nomer 15 dan 16 kenapa ragu-ragu, kamu ngerasanya tadi bingung gak sewaktu mengerjakan?

S304 : iya sih ada bingungnya, tapi gak telalu juga makanya saya jawab ragu-ragu

P305 : merasa takut saat tidak menemukan jawabannya gak?

S305 : saya sih sempat tidak menemukan jawaban, tapi setelah mengingat lagi saya akhirnya bisa menjawabnya

P306 : berarti sudah teratasi ya yang sempet bingung dan takut itu, kemudian kamu merasa terganggu jika suasana gaduh ya?

S306 : iya tadi saya sempet cemas sewaktu mengerjakan kalo misalnya lingkungan sekitar rame, contoh sewaktu temen-temen udah banyak yang selesai itu

P307 : untuk pernyataan yang lain ini kenapa cenderung menjawab tidak sesuai daripada sangat tidak sesuai? Memang benar tidak mengalami atau mengalami tapi cenderung sedikit?

S307 : nah itu, saya mengalaminya beberapa tapi menurut saya itu gak terlalu juga gitu hehe. Maksudnya kayak kesulitan berfikir terus lupa materi gitu saya mengalami cuman setelah itu sudah

P308 : dari tes geometri tadi, kamu ngerasa mengalami kecemasan gak menurutmu? Terus apa mengalami kesulitan saat mengerjakan?

S308 : cemas, tapi menurut saya cemasnya masih yang wajar aja gitu. Kayak masih bisa saya kendalikan lah intinya. Kalau kesulitannya saya pada soal yang berupa permasalahan gitu bu, karena kadang bingung mau diapakan hehe

Jawaban Subjek S3 pada soal nomor 3 dan 4 sudah tepat, walaupun ia mengatakan bahwa sempat mengalami kecemasan tetapi hasil pekerjaan S3 tidak mengalami dampak negatif. Kemudian dilakukan analisis lebih dalam dari lembar jawaban S3, ternyata S3 dalam mendefinisikan limas dan kubus sudah mampu menyertakan unsur dari bangun ruang. Selain itu, S3 juga mampu menyebutkan unsur-unsur yang diminta pada soal akan tetapi ia tidak memberikan jawaban untuk unsur bidang diagonal. Saat kegiatan wawancara S3 menegaskan kembali bahwa dirinya mengalami sedikit gejala kecemasan pada fisiologis dan mengalami gejala pada perilaku kognitif dan afektif. Berdasarkan penelitian yang dilakukan subjek S3 mengalami kecemasan kategori sedang.

Subjek S4 merasakan sedikit kecemasan di awal tes melalui gejala fisiologis, yakni jantung sedikit berdebar, tidak bisa diam dan ada tekanan pada dada. S4 mengalami gejala perilaku seperti lupa materi, bingung, gelisah, sulit berkonsentrasi dan takut gagal. Subjek S4 mengalami kecemasan dalam menyelesaikan masalah geometri bangun ruang sisi datar yang berkaitan dengan perhitungan. Berikut hasil jawaban S4 dengan tingkat kecemasan sedang. 
Kecemasan Geometri Siswa dalam Menyelesaikan Masalah Bangun Ruang Sisi Datar Ditinjau dari Teori Van Hiele, Erfan Yudianto, Yufrida Septi Nindya, Toto' Bara Setiawan

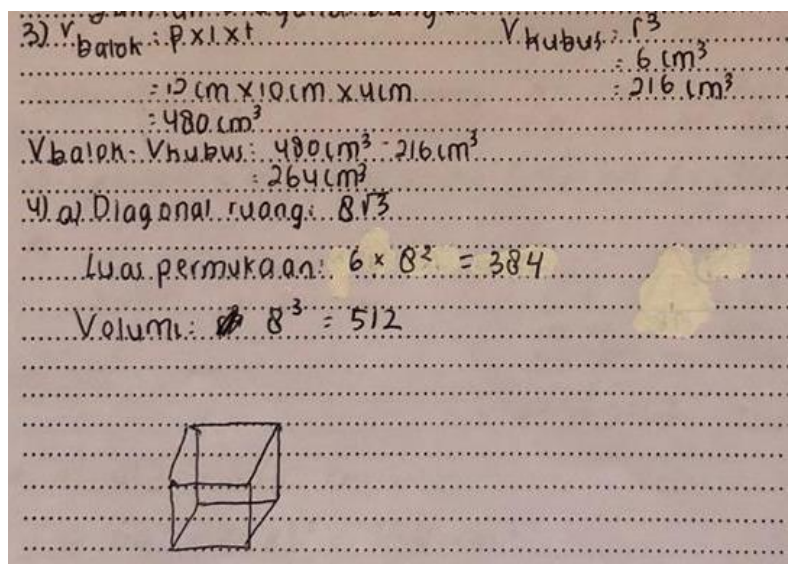

Gambar 4. Jawaban S4 Soal Nomor 3 dan 4

Selanjutnya untuk menelusuri lebih dalam mengenai kecemasan geometri S4 dilakukan kegiatan wawancara terkait angket dan jawaban subjek, berikut kutipan wawancara dengan Subjek S4.

P401 : kenapa menjawab ragu-ragu pada tidak bisa diam saat mengerjakan tes?

S401 : iya saya tidak bisa diam tapi di waktu tertentu aja

P402 : contohnya waktu apa? Terus ini jantung berdebar dan tekanan pada dada memang tidak merasakan?

S402 : merasakan sedikit diawal aja jadi semacam dredeg gitu, tapi pas sudah lagi ngerjakan enggak. Terus itu gak bisa diamnya kayak tangan main-mainin bolpoin gitu

P403 : punya riwayat sakit mungkin? Nah itu kamu main-main bolpoin kenapa kira-kira?

S403 : tidak punya riwayat sakit, ya saya kebiasaan sih bu kayak gitu buat tenang juga biar gak dredeg kayak di awal

P404 : kamu sempat lupa materi kah?

S404 : iya, itu kayak bawaan grogi gitu. Jadi tiba-tiba kayak blank materi ini, padahal kan ini materi bangun ruang sisi datar sudah pernah gitu

P405 : terus sewaktu lupa materi bingung berarti ngerjakan tesnya?

S405 : bingung jadi tadi saya sempet ngerjakan yang inget-inget dulu. Sewaktu udah mulai inget materi baru deh dikerjakan yang lain

P406 : kamu sempet jawab asal-asalan gak? Terus udah yakin belum sama jawabanmu?

S406 : kalau asal-asalan enggak bu, saya jawab sesuai apa yang saya inget aja gitu gak ngasal. Iya saya udah yakin

P407 : kalau suasana gaduh apa kamu tetep bisa tenang ngerjakannya?

S407 : rada gak tenang, ganggu konsentrasi semisal rame lingkungannya

Subjek S4 mengatakan bahwa dirinya sempat mengalami lupa materi. Namun, saat dianalisis lembar jawaban S4 ia mampu menjawab dari semua soal. Jawaban subjek S4 pada soal perhitungan sudah benar. Namun, ia tidak memberikan jawaban pada unsur bidang diagonal. Dalam mendefinisikan bangun S4 mampu mengidentifikasi dan menentukan ciri-ciri bangun tersebut berdasarkan sifatnya, seperti bagian yang sejajar dan sama panjang. Saat kegiatan wawancara S4 menegaskan kembali bahwa dirinya mengalami gejala kecemasan pada fisiologis dan perilaku kognitif dan afektif. Berdasarkan penelitian yang dilakukan subjek S4 mengalami kecemasan kategori sedang.

Subjek S5 merasakan kecemasan melalui gejala fisiologis, seperti jantung berdebar, susah tidur dan tidak bisa diam. Pada gejala perilaku subjek S5 mengalami gejala kecemasan seperti hambat berfikir, sulit berkonsentrasi, lupa materi, khawatir, takut gagal dan bingung. Subjek S5 mengalami 
kecemasan dalam menyelesaikan masalah geometri yang berkaitan dengan definisi dan unsur-unsur bangun ruang sisi datar serta soal dalam bentuk cerita. Berikut hasil jawaban S5 dengan tingkat kecemasan tinggi.

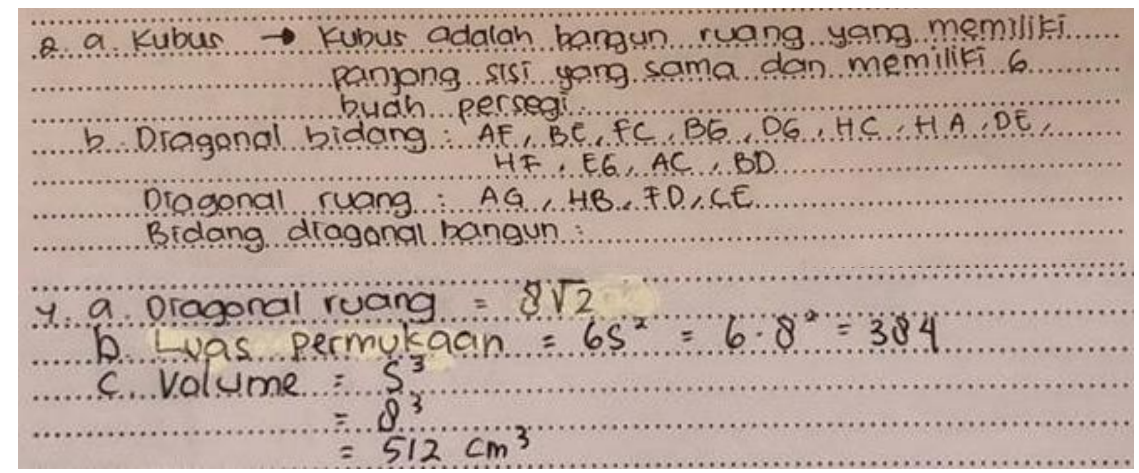

Gambar 5. Jawaban S5 Soal Nomor 2 dan 4

Selanjutnya untuk menelusuri lebih dalam mengenai kecemasan geometri S5 dilakukan kegiatan wawancara terkait angket dan jawaban subjek, berikut kutipan wawancara dengan Subjek S5.

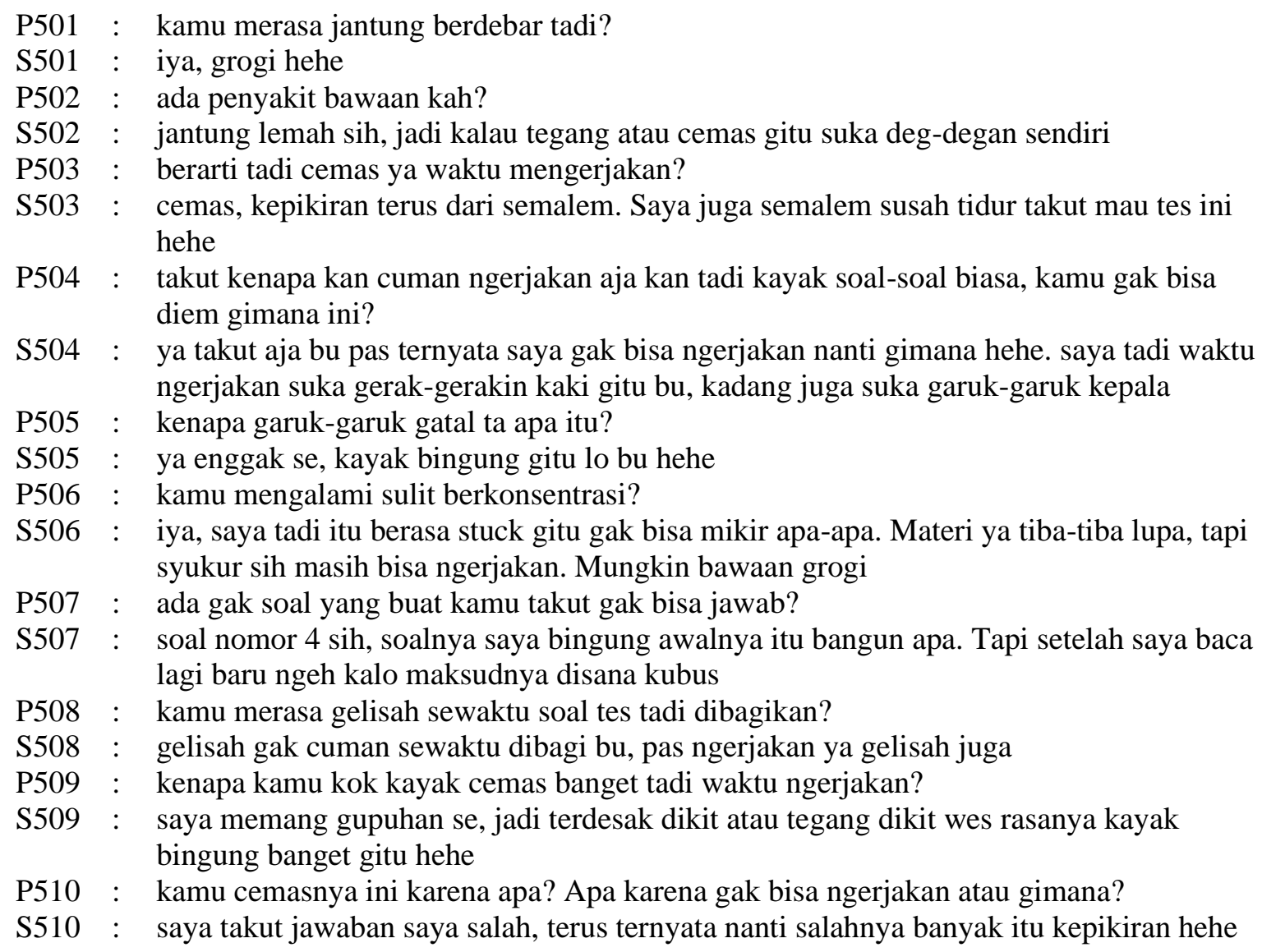

Subjek S5 mengatakan bahwa ia sempat mengalami hambatan berfikir sehingga mengalami kesulitan dalam menjawab soal nomor 4. Setelah ditelusuri ternyata subjek S5 masih belum tepat pada perhitungan diagonal ruang, namun untuk perhitungan luas permukaan dan volume jawaban S5 sudah tepat. Saat ditelusuri jawaban S5 dalam membuat definisi ternyata S5 mampu menyebutkan unsur pada 
Kecemasan Geometri Siswa dalam Menyelesaikan Masalah Bangun Ruang Sisi Datar Ditinjau dari Teori Van Hiele, Erfan Yudianto, Yufrida Septi Nindya, Toto' Bara Setiawan

bangun tetapi tidak dengan sifatnya. Saat kegiatan wawancara S5 menegaskan kembali bahwa dirinya mengalami gejala kecemasan pada fisiologis dan perilaku kognitif dan afektif. Berdasarkan penelitian yang dilakukan subjek S5 mengalami kecemasan kategori sedang.

Subjek S6 merasakan kecemasan melalui gejala fisiologis, seperti tekanan pada dada, sulit bernafas, dan berkeringat. Subjek S6 juga mengalami gejala perilaku kognitif seperti sulit berkonsentrasi, lupa materi, khawatir, konsentrasi terganggu, dan bingung. S6 mengalami kecemasan dalam menyelesaikan masalah berbemtuk cerita. Berikut hasil jawaban S6 dengan tingkat kecemasan tinggi.

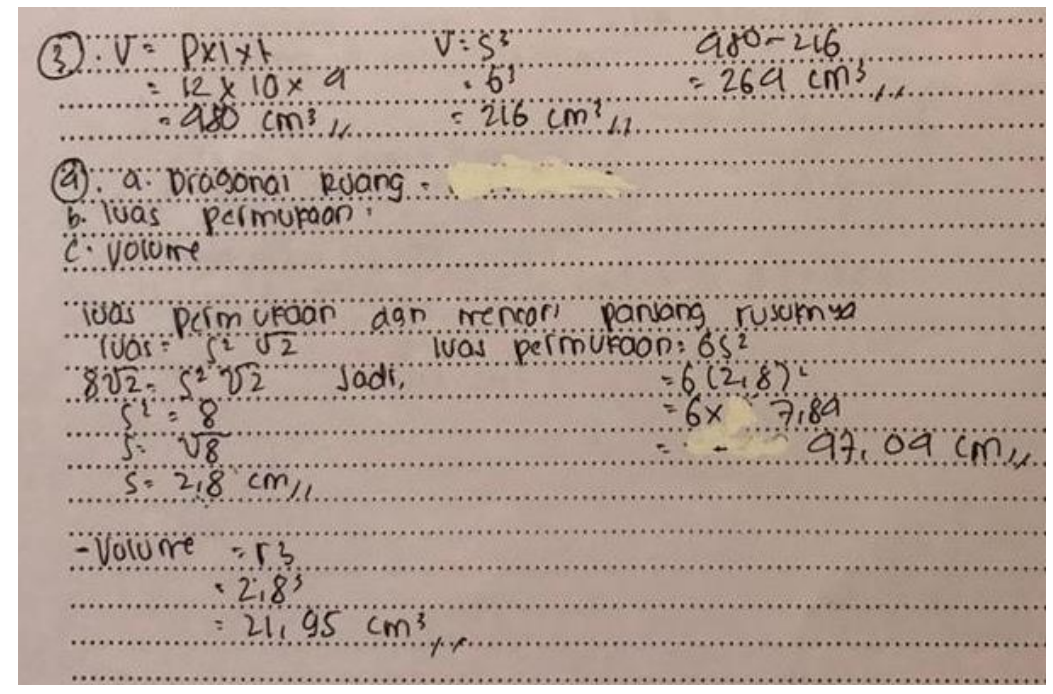

Gambar 6. Jawaban S6 Soal Nomor 3 dan 4

Selanjutnya untuk menelusuri lebih dalam mengenai kecemasan geometri S6 dilakukan kegiatan wawancara terkait angket dan jawaban subjek, berikut kutipan wawancara dengan Subjek S6.

P601 : kamu merasa ada tekanan pada dada dan susah bernafas kah?

S601 : iya merasa tadi waktu ngerjakan soal geometri itu

P602 : apa kamu punya riwayat sakit yang berhubungan sama pernafasan kah?

S602 : saya pernah sih emang ngerasa sesek gitu semisal lagi terdesak, jadi kayak ada tekanan di dada sampe akhirnya nafas agak sulit

P603 : kalau sewaktu ngerjakan tadi menurut kamu apa sebab yang membuat tubuhmu jadi ngerasa sesak gitu?

S603 : saya grogi waktu ngerjakan soal geometri tadi

P604 : sempat berkeringat juga? Itu juga karena cemas atau ada faktor yang lain?

S604 : iya cemas

P605 : sulit berkonsentrasi kah tadi?

S605 : iya, waktu suasana sedikit gaduh juga saya jadi gak konsentrasi

P606 : tapi waktu susah konsentrasi itu sampai buat lupa materi atau tidak?

S606 : sempet lupa juga, akhirnya saya bingung tadi waktu jawab soal nomor 2 yang tentang diagonal

P607 : sewaktu kamu kebingungan itu ada rasa khawatir kalau gak bisa jawab gak?

S607 : iya, saya sampek berusaha nginget-nginget terus tadi itu. Tapi untung akhirnya bisa jawab hehe

P608 : kamu merasa gelisah sewaktu soal tes tadi dibagikan?

S608 : iya hehe, saya takut soalnya susah

P609 : tapi setelah dikerjakan gimana? 
S609 : sebenernya ya gak susah banget, cuman karena saya cemas itu jadi jadi banyak yang lupa. Padahal kalo dipikir ya bisa aja lancar asal tadi konsentrasinya gak bubar

P610 : kamu merasa suasana tadi gaduh engga? terus apa itu ngeganggu kamu sewaktu mengerjakan?

S610 : sempet gaduh sewaktu saya dan beberapa temen sudah selesai sih. Tapi kalo sewaktu mengerjakan sebenernya ya tenang-tenang aja

P611 : tadi akhirnya kan kamu yang pertama selesai, emang pingin cepet-cepet apa gimana?

S611 : huuh iya saya ngerasanya udah wes daripada saya kepikiran terus ini bener apa salah, jadi akhirnya saya kumpulkan dulu

Hasil jawaban S6 mengenai soal berbentuk cerita terlihat untuk soal nomor 3 sudah benar, namun pada soal nomor 4 masih salah. Kejadian ini memungkinkan akibat tingginya kecemasan yang terjadi pada subjek. Kemudian ditelusuri jawaban S6 dalam mendefinisikan bangun, subjek S6 mampu menyebutkan unsur bangun ruang namun masih salah dalam menyebutkan sifat-sifat geometri. Saat kegiatan wawancara S6 menegaskan kembali bahwa dirinya mengalami gejala kecemasan pada fisiologis dan perilaku kognitif dan afektif. Berdasarkan penelitian yang dilakukan subjek S6 mengalami kecemasan kategori sedang.

\section{Pembahasan}

Subjek visualisasi pada penelitian ini mengalami kecemasan sedang dan tinggi, subjek dengan level analisis mengalami kecemasan sedang, serta subjek dengan level deduksi informal mengalami kecemasan tinggi. Keenam subjek ini dikategorikan kecemasannya berdasarkan hasil angket yang berisikan pernyataan berupa kondisi yang dialami berdasarkan indikator kecemasan Stuart (2006). Siswa yang berada pada level visualisasi sudah mengenal bangun - bangun geometri seperti segitiga, persegi, persegipanjang, jajargenjang (Pavlovičová \& Švecová, 2015; Sunardi et al., 2019; Yudianto \& Sunardi, 2015; Yuliana \& Ratu, 2019). Bentuk geometri yang dikenal siswa visualisasi hanya berdasarkan karakteristik visual atau penampakan bentuk secara keseluruhan. Sesuai dengan teori tersebut subjek visualisasi merasakan kecemasan saat membuat definisi bangun, mereka mengatakan bahwa terjadi gejala kecemasan seperti bingung saat mendefinisikan bangun. Setelah ditinjau pada lembar jawaban subjek visualisasi, ternyata mereka mendefinisikan bangun pada soal sesuai dengan penampakan dan karakteristik yang mereka lihat tanpa memberikan sifat geometri pada bangun. Kecemasan geometri yang subjek visualisasi alami dari gejala fisiologis (tekanan pada dada, jantung berdebar, tidak bisa diam, berkeringat, dan tidak dapat menahan kencing) dan gejala perilaku (tidak fokus, lupa materi, bingung, sulit berkonsentrasi, hambatan berfikir, takut, mudah terganggu, tidak sabar, gelisah, khawatir, tegang, gugup, dan grogi). Siswa level analisis dapat mengenal sifat-sifat bentuk geometris berdasarkan analisis informal berbagai bagian bentuk dan jika siswa mampu berpikir secara kritis maka akan maksimal (Eviyanti, Rista, \& Hadijah, 2020; Maharani \& Prihatnani, 2019; Sunardi \& Yudianto, 2016). Pada level ini siswa dapat mengidentifikasi dan menentukan ciri-ciri bangun berdasarkan sifat-sifatnya. Namun, subjek penelitian yang berada pada level analisis beranggapan tidak terlalu mengalami kecemasan geometri saat mendefinisikan bangun. Setelah ditelusuri melalui kegiatan 
Kecemasan Geometri Siswa dalam Menyelesaikan Masalah Bangun Ruang Sisi Datar Ditinjau dari Teori Van Hiele, Erfan Yudianto, Yufrida Septi Nindya, Toto' Bara Setiawan

wawancara, subjek level analisis mengatakan bahwa mengalami kecemasan saat menghadapi permasalahan perhitungan. Jawaban subjek analisis pada soal perhitungan sudah benar, bahkan subjek analisis mampu menjawab semua soal yang diberikan. Hal ini berarti rendahnya tingkat kecemasan geometri yang dialami subjek analisis membawa dampak baik. Kecemasan geometri yang subjek analisis alami dari gejala fisiologis (jantung berdebar, berkeringat, tekanan pada dada, dan tidak bisa diam) dan gejala perilaku (tidak fokus, lupa materi, bingung, konsentrasi buruk, takut, gelisah, merasa tidak yakin, dan mudah terganggu). Siswa deduksi informal dapat melihat hubungan antar sifat-sifat dalam satu bangun maupun diantara beberapa bangun, dan dapat mengurutkan sifat-sifat bangun secara logis (Pavlovičová \& Švecová, 2015; Sunardi et al., 2019; Yudianto \& Sunardi, 2015). Subjek level deduksi informal pada penelitian ini cenderung mengalami kecemasan pada permasalahan berbentuk cerita, pada kegiatan wawancara subjek deduksi informal juga mengatakan bahwa mengalami kecemasan saat dihadapkan dengan permasalahan unsur-unsur bangun ruang sisi datar. jawaban subjek deduksi informal masih terdapat kesalahan, namun dalam mendefinisikan bangun subjek deduksi informal mampu menyebutkan unsur bangun ruang namun masih salah dalam menyebutkan sifat-sifat geometri Kecemasan geometri yang subjek deduksi informal alami dari gejala fisiologis (jantung berdebar, susah tidur, tidak bisa diam, tekanan pada dada, sulit bernafas, berkeringat, dan wajah memerah) serta gejala perilaku (sulit berkonsentrasi, hambatan berfikir, lupa materi, bingung, tidak fokus, konsentrasi buruk, takut, mudah terganggu, tidak sabar, gelisah, tegang, gugup, malu atau grogi, khawatir, dan merasa tidak yakin).

Penelitian ini memiliki hasil bahwa tingkat berfikir geometri siswa tidak dapat menjamin tingkat kecemasannya. Artinya tidak ada relasi atau hubungan antara keduanya. Beberapa subjek pada penelitian ini mengalami kecemasan tinggi karena merasa takut dan kurang percaya diri dalam menghadapi masalah geometri bangun ruang sisi datar. Kecemasan dapat memberikan dampak yang berbeda pada setiap individu baik itu positif maupun negatif. Munculnya kecemasan karena beberapa faktor baik dari dalam diri subjek maupun lingkungan. Hal serupa juga dikemukaan Soehardjono \& Endang (1988), bahwa faktor yang mempengaruhi kecemasan yaitu mikrokosmos (keadaan diri individu) dan makrokosmos (keadaan luar individu). Penelitian yang dilakukan oleh Radisic, Videnovic \& Baucal (2015) menunjukkan bahwa kelompok yang menunjukkan kecemasan, memberi skor terendah dalam prestasi matematika. Sedangkan pada penelitian ini subjek yang berada pada level deduksi informal termasuk siswa dalam kategori cerdas, namun hasil penelitian mengungkapkan bahwa kecemasan keduanya cukup tinggi. Penelitian ini dapat membuktikan bahwa semakin tinggi level berfikir geometri siswa tidak menjamin semakin rendahnya kecemasan geometri yang dialami siswa. Hal ini dikarenakan kecemasan bukan merupakan hal negatif yang selalu membawa dampak buruk, namun kecemasan merupakan kondisi alamiah yang dapat dialami manusia saat berada pada keadaan terdesak ataupun khawatir terhadap suatu hal. Peristiwa kecemasan geometri yang terjadi pada penelitian ini didasari dengan teori bahwa tingkat kecemasan siswa tergantung oleh keadaan diri individu dan keadaan luar individu seperti diungkapkan oleh Soehardjono \& Endang (1988). 


\section{KESIMPULAN}

Subjek level visualisasi mengalami kecemasan geometri sedang dan tinggi ketika mendefinisikan bangun, menentukan diagonal-diagonal bangun, dan menentukan bentuk bangun berdasarkan ciri-cirinya. Saat mengerjakan masalah bangun ruang sisi datar subjek mengalami kecemasan dari segi gejala fisiologis (tekanan pada dada, jantung berdebar, tidak bisa diam, berkeringat, dan tidak dapat menahan kencing) dan gejala perilaku (tidak fokus, lupa materi, bingung, sulit berkonsentrasi, hambatan berfikir, takut, mudah terganggu, tidak sabar, gelisah, khawatir, tegang, gugup, dan grogi). Subjek level analisis mengalami kecemasan geometri sedang ketika menyelesaikan permasalahan geometri berupa soal cerita dan berkaitan dengan perhitungan. Subjek mengalami gejala fisiologis (jantung berdebar, berkeringat, tekanan pada dada, dan tidak bisa diam) dan gejala perilaku (tidak fokus, lupa materi, bingung, konsentrasi buruk, takut, gelisah, merasa tidak yakin, dan mudah terganggu). Subjek level deduksi informal mengalami kecemasan geometri tinggi ketika memahami soal dalam bentuk cerita dan saat menyelesaikan soal yang berkaitan dengan diagonal bangun ruang. Subjek mengalami gejala fisiologis (jantung berdebar, susah tidur, tidak bisa diam, tekanan pada dada, sulit bernafas, berkeringat, dan wajah memerah) serta gejala perilaku (sulit berkonsentrasi, hambatan berfikir, lupa materi, bingung, tidak fokus, konsentrasi buruk, takut, mudah terganggu, tidak sabar, gelisah, tegang, gugup, malu atau grogi, khawatir, dan merasa tidak yakin). Beberapa subjek pada penelitian ini mengalami kecemasan tinggi karena merasa takut dan kurang percaya diri dalam menghadapi masalah geometri bangun ruang sisi datar. Munculnya perasaan tersebut karena beberapa faktor baik dari dalam diri subjek maupun lingkungan. Sehingga level berfikir geometri siswa tidak memiliki jaminan terhadap rendahnya kecemasan geometri yang terjadi pada siswa. Saran untuk peneliti selanjutnya diharapkan dapat mengembangkan ke ranah penelitian lain yang sejenis, baik mengenai kecemasan geometri, masalah geometri bangun ruang sisi datar maupun teori van Hiele.

\section{UCAPAN TERIMA KASIH}

Terima kasih yang tak terhingga kepada siswa-siswa, kepala sekolah dan guru matematika SMAN 2 Jember telah memberikan dan meluangkan waktu kepada tim peneliti. Khususnya XI IPS 1 dan XI IPS 2 SMA Negeri 2 Jember.

\section{REFERENSI}

Anita, I. W. (2014). Pengaruh Kecemasan Matematika (Mathematics Anxiety) Terhadap Kemampuan Koneksi Matematis Siswa SMP. Infinity Journal. https://doi.org/10.22460/infinity.v3i1.43

Annisa, D. F., \& Ifdil, I. (2016). Konsep Kecemasan (Anxiety). Konselor. https://doi.org/10.24036/02016526480-0-00

Auliya, R. N. (2016). Kecemasan Matematika dan Pemahaman Matematis. Formatif: Jurnal Ilmiah Pendidikan MIPA. https://doi.org/10.30998/formatif.v6i1.748 
Eviyanti, C. Y., Rista, L., \& Hadijah, S. (2020). Penerapan Model Pembelajaran Investigasi Kelompok Melalui Media Domino Matematika. Juenal Cendekia, 04(02), 999-1010.

Fuys, D., Geddes, D., \& Tischler, R. (1998). The Van Hiele Model of Thinking in Geometry Among Adolescents. Journal for Research in Mathematics Education, 3, 1-196.

Maharani, A. F., \& Prihatnani, E. (2019). Newman' S Error Analysis Dalam Geometri Ruang. Jurnal Cendekia, 03(02), 447-461.

Moleong, L. J. (2001). Metode Penelitian Kuantitatif. Bandung: PT. Remaja Rosdakarya.

Pavlovičová, G., \& Švecová, V. (2015). The Development of Spatial Skills through Discovering in the Geometrical Education at Primary School. Procedia - Social and Behavioral Sciences, 186, 990997. https://doi.org/10.1016/j.sbspro.2015.04.189

Radisic, J., Videnovic, M., \& Baucal, A. (2015). Math anxiety-Contriuting School and Individual Level Factors. Eur J Psychol Education, 30, 1-20.

Soehardjono, L., \& Endang W.G. (1988). Kecemasan pada Anak dan Remaja. Majalah Anima : Media Psikologi Indonesia.

Stuart, G. W. (2006). Buku Saku Keperawatan Jiwa. Jakarta: EGC.

Sunardi. (2001). Hubungan antara usia, tingkat berpikir dan kemampuan siswa dalam geometri. Prosiding Seminar Nasional Matematika "Peran Matematika Memasuki Milenium III". Jurusan Matematika FMIPA ITS Surabaya. Surabaya.

Sunardi, S., \& Yudianto, E. (2016). Antisipasi Siswa Level Analisis Dalam Menyelesaikan Masalah Geometri. AdMathEdu : Jurnal Ilmiah Pendidikan Matematika, Ilmu Matematika Dan Matematika Terapan, 5(2). https://doi.org/10.12928/admathedu.v5i2.4776

Sunardi, Yudianto, E., Susanto, Kurniati, D., Cahyo, R. D., \& Subanji. (2019). Anxiety of students in visualization, analysis, and informal deduction levels to solve geometry problems. International Journal of Learning, Teaching and Educational Research. https://doi.org/10.26803/ijlter.18.4.10

Yudianto, E, \& Sunardi. (2015). Antisipasi Siswa level Analisis dalam Menyelesaikan Masalah Geometri. AdMathEdu, 5(2), 203-216.

Yudianto, Erfan. (2011). Yudianto (2007). Perkembangan Kognitif Siswa Sekolah Dasar di Jember Kota Berdasarkan Teori van Hiele. Skripsi tidak diterbitkan. Universitas Jember. (2000), 1-12.

Yuliana, D., \& Ratu, N. (2019). Analisis Keterampilan Dasar Visual Geometri Siswa SMP Ditinjau Berdasarkan Level Berpikir Analisis Van Hiele. Jurnal Cendekia, 3(2), 536-549. https://doi.org/10.31004/cendekia.v3i2.135 